\title{
Cumulative Effects of Particulate Matter Pollution and Meteorological Variables on the Risk of Influenza-Like Illness
}

\author{
Kacper Toczylowski ${ }^{1, *(\mathbb{D}, \text { Magdalena Wietlicka-Piszcz }}{ }^{2,3}$, Magdalena Grabowska ${ }^{4}$ and Artur Sulik $^{1}$ (D) \\ 1 Department of Pediatric Infectious Diseases, Medical University of Bialystok, Waszyngtona 17, \\ 15-274 Bialystok, Poland; artur.sulik@umb.edu.pl \\ 2 Department of Theoretical Foundations of Biomedical Sciences and Medical Computer Science, L. Rydygier \\ Collegium Medicum in Bydgoszcz, Nicolaus Copernicus University in Torun, 9 M. Sklodowska-Curie St., \\ 85-094 Bydgoszcz, Poland; mpiszcz@cm.umk.pl \\ 3 Parexel International, Zwirki i Wigury 18A, 02-092 Warsaw, Poland \\ 4 Department of Hydrobiology, University of Bialystok, Ciolkowskiego 1J, 15-245 Bialystok, Poland; \\ magra@uwb.edu.pl \\ * Correspondence: kacper.toczylowski@umb.edu.pl; Tel.: +48-857-450-680
}

Citation: Toczylowski, K.;

Wietlicka-Piszcz, M.; Grabowska, M.; Sulik, A. Cumulative Effects of Particulate Matter Pollution and Meteorological Variables on the Risk of Influenza-Like Illness. Viruses 2021, 13, 556.

https://doi.org/10.3390/v13040556

Academic Editor: Daniel R Perez

Received: 25 January 2021

Accepted: 23 March 2021

Published: 26 March 2021

Publisher's Note: MDPI stays neutral with regard to jurisdictional claims in published maps and institutional affiliations.

Copyright: (c) 2021 by the authors. Licensee MDPI, Basel, Switzerland. This article is an open access article distributed under the terms and conditions of the Creative Commons Attribution (CC BY) license (https:// creativecommons.org/licenses/by/ $4.0 /)$.

\begin{abstract}
The cold season is usually accompanied by an increased incidence of respiratory infections and increased air pollution from combustion sources. As we are facing growing numbers of COVID-19 cases caused by the novel SARS-CoV-2 coronavirus, an understanding of the impact of air pollutants and meteorological variables on the incidence of respiratory infections is crucial. The incidence of influenza-like illness (ILI) can be used as a close proxy for the circulation of influenza viruses. Recently, SARS-CoV-2 has also been detected in patients with ILI. Using distributed lag nonlinear models, we analyzed the association between ILI, meteorological variables and particulate matter concentration in Bialystok, Poland, from 2013-2019. We found an exponential relationship between cumulative $\mathrm{PM}_{2.5}$ pollution and the incidence of ILI, which remained significant after adjusting for air temperatures and a long-term trend. Pollution had the greatest effect during the same week, but the risk of ILI was increased for the four following weeks. The risk of ILI was also increased by low air temperatures, low absolute humidity, and high wind speed. Altogether, our results show that all measures implemented to decrease $\mathrm{PM}_{2.5}$ concentrations would be beneficial to reduce the transmission of SARS-CoV-2 and other respiratory infections.
\end{abstract}

Keywords: particulate matter; air pollution; influenza; influenza-like illness; COVID-19

\section{Introduction}

Particulate matter (PM) is an important air pollutant. It comprises multiple components and size fractions. The size of the inhalable particles is limited to those with an aerodynamic diameter of $10 \mu \mathrm{m}$ or less $\left(\mathrm{PM}_{10}\right) . \mathrm{PM}_{10}$ includes fine particles with aerodynamic diameters of $2.5 \mu \mathrm{m}$ or less $\left(\mathrm{PM}_{2.5}\right)$ and coarse particles with aerodynamic diameters between $2.5 \mu \mathrm{m}$ and $10 \mu \mathrm{m}\left(\mathrm{PM}_{10-2.5}\right) . \mathrm{PM}_{2.5}$ originates primarily from combustion sources, while $\mathrm{PM}_{10-2.5}$ is produced by agriculture, mining, construction activities and road dust resuspension [1]. The health effects of particulate matter may differ because of differences in chemical composition and penetration into the respiratory tract [2]. Smaller particles have been shown to be more harmful to human health than larger particles because of the potential to be deposited in the alveoli and the ability to cross the lung-blood barrier [3]. The evidence for airborne particulate matter and its public health impact consistently shows adverse health effects at exposure levels that are currently experienced by urban populations in both developed and developing countries [1]. The range of health effects is broad. Exposure to air pollutants has been shown to be the cause of increased emergency room visits, exacerbation of chronic respiratory and cardiovascular diseases, decreased lung function, and premature mortality [2]. In response to the accumulating evidence on 
the adverse effects of air pollution, WHO published air quality guidelines with daily and annual thresholds for mean concentrations of $\mathrm{PM}_{2.5}$ and $\mathrm{PM}_{10}$. The guidelines stipulate that $\mathrm{PM}_{2.5}$ concentrations should not exceed a $25 \mu \mathrm{g} / \mathrm{m}^{3}$ daily mean or $10 \mu \mathrm{g} / \mathrm{m}^{3}$ annual mean. For $\mathrm{PM}_{10}$, concentration thresholds are $50 \mu \mathrm{g} / \mathrm{m}^{3}$ and $20 \mu \mathrm{g} / \mathrm{m}^{3}$ for daily and annual means, respectively [1].

Based on accumulating evidence, PM increases the incidence of influenza and influenzalike illness [4-6]. However, because of the difference in size and the ability to penetrate deep into the lungs, the effect might be stronger for $\mathrm{PM}_{2.5}$ than for $\mathrm{PM}_{10}$ [7]. Influenza-like illness (ILI) is a common acute respiratory syndrome defined by WHO as fever $\left(>38^{\circ} \mathrm{C}\right)$ with cough or sore throat, which began in the last 10 days [8]. Each year, ILI imposes a significant burden on public health and leads to substantial morbidity and economic costs $[9,10]$.

According to the latest $\mathrm{WHO}$ database of observed annual mean $\mathrm{PM}_{2.5}$ concentrations, air quality in Poland is considered unsafe, with many of Europe's 50 most polluted cities located in Poland [11]. High pollution levels in Polish cities are caused mainly by coal power plants and residential heating with wood and coal [12]. Following the recognition that Poland is facing high air pollution levels, researchers have focused on the associated health effects. However, little is known about the influence of air pollution on the respiratory infection incidence in Poland. In a recent study, Slama et al. reported a positive association between air pollutants and hospitalizations for respiratory disease in Polish cities [13]. This, and other studies have shown that people exposed to air pollutants may be at high risk for infection within a lag period of zero to ten days, which represents the usual incubation periods of respiratory infections $[4,14,15]$. Little is known about the effect of air pollution on respiratory infections beyond a lag of two weeks.

The current COVID-19 outbreak has been caused by the emergence of a new coronavirus, SARS-CoV-2, that very quickly spread in the human population. A similarity between COVID-19 and ILI symptoms has been observed. The presence of SARS-CoV-2positive swabs in patients with ILI has been reported in several studies [16-18]. Moreover, air pollution was suggested to be a major factor contributing to the aggressive spread of this virus [19]. Meteorological variables play an important role in the physical and chemical transformation of PM and its horizontal and vertical transport [20]. Therefore, we aimed to assess the association between the risk of ILI and air pollution over longer time lags, considering the potential influence of meteorological variables and long-term trends.

\section{Materials and Methods}

\subsection{Influenza-Like Illness Data}

Bialystok is the largest city in northeastern Poland and one of the largest cities in Poland in terms of population density (2913.8 people per sq. km). Bialystok City and Bialystok County cover an area of 3086.76 square kilometers and are inhabited by approximately 435,000 people, 297,000 (68\%) of whom live in Bialystok City [21]. The city has a warm, humid continental climate [22].

The data on the number of suspected influenza and influenza cases in Bialystok City and Bialystok County (Figure 1) were obtained from the Department of Epidemiology of the Municipal Sanitary and Epidemiological Station. Influenza is a notifiable disease in Poland. The Department collects all reports of confirmed and suspected influenza cases that come from all hospitals and all outpatient clinics located in the city and county. Reports of confirmed and suspected influenza cases (ICD-10 codes: J10.0, J10.1, J10.8, J11.0, J11.1, and J11.8) are submitted manually by hospitals and clinics with no automated reporting system integrated with medical document management software. The data are then reported weekly by the Municipal Sanitary and Epidemiological Station. No data on the percentage of confirmed cases in the total reported number are available. Therefore, throughout the manuscript, both confirmed and suspected influenza cases are analyzed jointly as ILIs. 

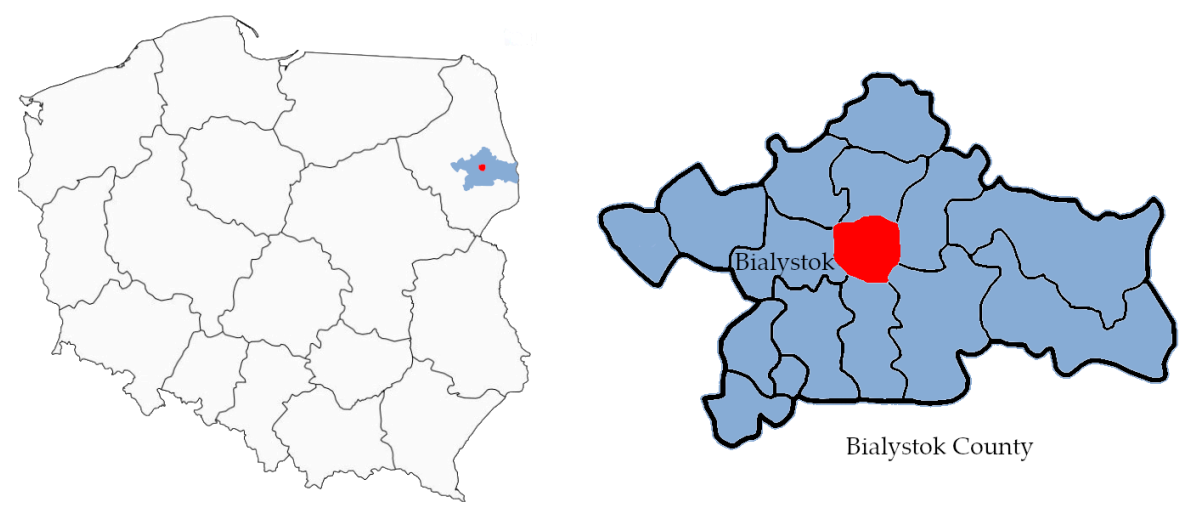

Figure 1. The geographical location of Bialystok and Bialystok County in northeastern Poland.

\subsection{Meteorological and Air Pollution Data}

The data on the concentration of air pollutants were obtained from two fixed stations, Waszyngtona Street and Warszawska Street, which are located two kilometers apart in the city center and have a maximum distance to the city borders of $6 \mathrm{~km}$. The concentrations of $\mathrm{PM}_{2.5}$ were measured with BAM 1020 (Met One Instruments Inc., OR, USA) (Waszyngtona Street), and the concentration of $\mathrm{PM}_{10}$ was measured with TEOM 1405F (Thermo Fisher Scientific, MA, USA) (Warszawska Street). Daily meteorological data (air temperature, relative humidity, wind speed, precipitation, precipitation and sunshine duration) for the analyzed period were obtained from the Institute of Meteorology and Water Management. Absolute humidity was calculated from temperature and relative humidity. For statistical analyses, we used mean weekly values. We found that $6 \%$ of the mean daily concentrations of $\mathrm{PM}_{2.5}$ were missing. Weeks with missing data for more than five days were excluded from the analysis.

\subsection{Statistical Analysis}

The patient and meteorological data collected from January 2013 to December 2019 were sorted, categorized according to weeks, and preliminarily analyzed with a simple correlation analysis (Spearman's r). Then, the association between meteorological factors, air pollution and the incidence of ILI was further studied with distributed lag nonlinear models (DLNMs) developed by Gasparrini [23]. The DLNM framework enables the modeling of the exposure-response relationship together with the lag-response relationship; thus, it enables the modeling of delayed effects after a specific exposure. In this paper, we used the DLNM to investigate the relationship between the incidence of ILI, meteorological factors and air pollution expressed as the levels of $\mathrm{PM}_{2.5}$ and $\mathrm{PM}_{10}$. The delayed effects of the abovementioned environmental factors were also studied.

The modeling of the relationship between the incidence of ILI and the environmental factors was performed for the following meteorological factors: air temperature, relative humidity, absolute humidity, sunshine duration, precipitation, precipitation duration, and wind speed and for air pollution expressed as the levels of $\mathrm{PM}_{2.5}$ and $\mathrm{PM}_{10}$. Poisson regression models with a quasi-Poisson function were used for the analysis to address the issue of the overdispersion of the response data (counts of ILI cases). The number of ILI cases was included in the model as the dependent variable, while the considered environmental factors were included as independent variables. The following formula represents the model structure:

$$
\log \left[\mathrm{E}\left(Y_{t}\right)\right]=\alpha+n s\left(X_{i}, d f\right)+n s(P M, d f, l a g, d f)+n s(\text { Time }, d f)
$$

where $\mathrm{E}\left(Y_{t}\right)$ represents the weekly number of ILI cases in week $t, \alpha$ is the intercept, $X_{i}$ represents the environmental factors (temperature, etc.), ns is the natural cubic spline, PM is the concentration of particulate matter, $\mathrm{df}$ represents the degree of freedom, and Time represents the long-term trend. 
Initially, the analysis was performed for each environmental factor separately, and then the models adjusted for air pollutant levels were fitted to the data. Because of the relatively strong correlations between the meteorological factors, one meteorological factor, one air pollutant and the long-term trend were included in each model. The Akaike information criterion for quasi-Poisson function (qAIC) was used to select the degrees of freedom for environmental factors (1-10 df) and for the maximum number of lag weeks included in the model [24]. According to the results of the analysis (lowest value of qAIC) and previous studies [25-27], we decided to include the delayed effects for $\mathrm{PM}_{2.5}$ and for wind speed. The effects of the meteorological factors, temperature, wind speed and precipitation were modeled using $1 \mathrm{df}$, sunshine duration $4 \mathrm{df}$, humidity $3 \mathrm{df}$ and precipitation duration $2 \mathrm{df}$. For wind speed, the maximum lag of 2 weeks was included (a range of 1-8 maximum weeks of lag). The effects of air pollution caused by $\mathrm{PM}_{2.5}$ and $\mathrm{PM}_{10}$ were modeled by ns of $1 \mathrm{df}$, and for $\mathrm{PM}_{2.5}$, the maximum lag of 5 weeks was also included. The maximum lag was chosen based on the qAIC and the stability of the shape of the risk of the ILI-PM 2.5 relationship. The long-term trend was modeled using ns with $1 \mathrm{df} /$ year.

The reference levels were defined as the median values of each of the analyzed variables, to calculate relative risks (RRs). The sensitivity analysis was performed by calculating the qAIC and changing $\mathrm{df}$ for environmental variables.

The statistical analysis was performed using $R$ software, version 3.6.2, with the packages dlnm, mgcv and bbmle (The R Foundation for Statistical Computing, Vienna, Austria).

\section{Results}

\subsection{Influenza-Like Illness Activity in 2013-2019}

During the analyzed period, 345,987 cases were reported, of which $155,249(45 \%)$ were children under the age of 15, and 31,179 (9\%) were individuals over 65 years of age (Table S1, Supplementary Materials). The incidence rate based on the number of reported cases was 11.4 (95\% CI, 11.3-11.5) episodes per 100 person-years. Data on the sex of the patients were unavailable. The median number of cases in a week was 700 (ranging from 0 cases to 6309 cases). The number of ILI cases peaked once in each season, in January and February, when the mean temperatures approached $0{ }^{\circ} \mathrm{C}$ (Figure S1, Supplementary Materials).

\subsection{Air Pollution and Meteorological Data}

Concentrations of $\mathrm{PM}_{2.5}$ and $\mathrm{PM}_{10}$ increased in the fall and in the winter (Figure S1, Supplementary Materials). The daily mean concentrations of $\mathrm{PM}_{2.5}$ exceeded WHO standards on $767(30 \%)$ days and that of $\mathrm{PM}_{10}$ exceeded the standards on $129(5 \%)$ days. The annual mean concentrations of $\mathrm{PM}_{2.5}$ exceeded the standards every year, and those of $\mathrm{PM}_{10}$ were within the recommended levels in 2019 only (Table S2, Supplementary Materials). From 2013 to 2019, the weekly mean concentration of $\mathrm{PM}_{2.5}$ was $22.41 \mu \mathrm{g} / \mathrm{m}^{3}$, ranging from $9.04 \mu \mathrm{g} / \mathrm{m}^{3}$ to $49.77 \mu \mathrm{g} / \mathrm{m}^{3}$, and that of $\mathrm{PM}_{10}$ was $22.34 \mu \mathrm{g} / \mathrm{m}^{3}$, ranging from $6.56 \mu \mathrm{g} / \mathrm{m}^{3}$ to $55.99 \mathrm{\mu g} / \mathrm{m}^{3}$ (Table 1 ). The weekly mean temperature was $8.28{ }^{\circ} \mathrm{C}$, ranging from $-12.90{ }^{\circ} \mathrm{C}$ to $23.11^{\circ} \mathrm{C}$. The average weekly relative humidity (RH) was $79.3 \%$ (ranging from $45.46 \%$ to $97.30 \%$ ), absolute humidity (AH) was $7.3 \mathrm{~g} / \mathrm{m}^{3}$ (ranging from 1.34 to $15.91 \mathrm{~g} / \mathrm{m}^{3}$ ), wind speed was $2.40 \mathrm{~m} / \mathrm{s}$ (ranging from $1.05 \mathrm{~m} / \mathrm{s}$ to $4.66 \mathrm{~m} / \mathrm{s}$ ), precipitation was $1.79 \mathrm{~mm}$ (ranging from $0.0 \mathrm{~mm}$ to $13.29 \mathrm{~mm}$ ), precipitation duration was $3.09 \mathrm{~h}$ (ranging from $0.0 \mathrm{~h}$ to $13.85 \mathrm{~h}$ ), and sunshine duration was $4.99 \mathrm{~h}$ (ranging from $0.0 \mathrm{~h}$ to $14.59 \mathrm{~h}$ ).

\subsection{Correlations between Influenza-Like Illness Cases and Meteorological Data}

The analysis of Spearman correlations showed that the incidence of ILI was positively correlated with weekly mean values of relative humidity, wind speed, precipitation duration, concentration of $\mathrm{PM}_{2.5}$ and concentration of $\mathrm{PM}_{10}$. In contrast, weekly mean values for temperature, precipitation, and sunshine durations were negatively correlated with the incidence of ILI (Table S3, Supplementary Materials). When correlations were analyzed in the peak of the flu season only (December-February), ILI cases correlated with $\mathrm{PM}_{2.5}$ $(\mathrm{R}=0.31, p=0.007), \mathrm{PM}_{10}(\mathrm{R}=0.27 ; p=0.02)$, mean temperature $(\mathrm{R}=-0.25 ; p=0.02)$, 
and absolute humidity ( $\mathrm{R}=-0.30 ; p=0.005)$. No correlation with relative humidity, wind speed, sunshine duration or precipitation was observed in that time frame.

Table 1. Weekly meteorological variables, air pollutants and the incidence of influenza-like illness in Bialystok, January 2013-December 2019.

\begin{tabular}{|c|c|c|c|c|c|c|c|c|c|}
\hline & Mean & SD & Min & P5 & P25 & Median & P75 & P95 & $\operatorname{Max}$ \\
\hline Number of cases of ILI & 1029.72 & 1034.50 & 0.00 & 108.0 & 313.75 & 700.00 & 1280.50 & 3227.0 & 6309.00 \\
\hline Temperature $\left({ }^{\circ} \mathrm{C}\right)$ & 8.28 & 8.03 & -12.90 & -5.51 & 2.02 & 7.99 & 15.83 & 21.00 & 23.11 \\
\hline Relative humidity (\%) & 79.30 & 9.81 & 45.46 & 57.50 & 72.28 & 80.51 & 87.52 & 96.40 & 97.30 \\
\hline $\begin{array}{l}\text { Absolute humidity } \\
\qquad\left(\mathrm{g} / \mathrm{m}^{3}\right)\end{array}$ & 7.30 & 3.18 & 1.34 & 2.97 & 4.65 & 6.92 & 10.00 & 12.79 & 15.91 \\
\hline Wind speed (m/s) & 2.40 & 0.57 & 1.05 & 1.00 & 2.01 & 2.33 & 2.71 & 4.10 & 4.66 \\
\hline Precipitation (mm) & 1.79 & 2.09 & 0.00 & 0.00 & 0.29 & 1.06 & 2.46 & 9.82 & 13.29 \\
\hline $\begin{array}{c}\text { Precipitation duration } \\
\text { (hours) }\end{array}$ & 3.09 & 2.75 & 0.00 & 0.00 & 1.00 & 2.35 & 4.46 & 13.40 & 13.85 \\
\hline $\begin{array}{l}\text { Sunshine duration } \\
\text { (hours) }\end{array}$ & 4.99 & 3.75 & 0.00 & 0.20 & 1.42 & 4.88 & 7.93 & 13.16 & 14.59 \\
\hline $\mathrm{PM}_{2.5}\left(\mu \mathrm{g} / \mathrm{m}^{3}\right)$ & 22.34 & 7.96 & 6.56 & 7.50 & 15.26 & 19.60 & 26.86 & 44.70 & 49.77 \\
\hline $\mathrm{PM}_{10}\left(\mu \mathrm{g} / \mathrm{m}^{3}\right)$ & 22.41 & 9.93 & 9.04 & 8.60 & 16.83 & 20.39 & 26.90 & 50.42 & 55.99 \\
\hline
\end{tabular}

Abbreviations: ILI, influenza-like illness; $\mathrm{PM}_{2.5}$, particulate matter with an aerodynamic diameter of $2.5 \mu \mathrm{m}$ or less; $\mathrm{PM}_{10}$, particulate matter with an aerodynamic diameter of $10 \mu \mathrm{m}$ or less.

\subsection{Non-Linear Univariable Models}

For each of the variables described above, a DLNM model illustrating the relationship between the number of ILI cases and the values of the considered variable was fitted. The delayed effect was included for $\mathrm{PM}_{2.5}$. The results of the model estimation are presented as relative risks (RRs) and are shown in Figure S2 in the Supplementary Materials. For each considered environmental variable, the association between the RR of ILI and the values of weekly means of the covariate are shown. As shown in Figure S2, the weekly mean temperature and weekly mean concentrations of $\mathrm{PM}_{2.5}$ were the most significant risk factors exponentially associated with the incidence of ILI, as evidenced by the highest relative risks (RRs). The values of the coefficient of determination $\left(R^{2}\right)$ were 0.523 and 0.565 , respectively, which indicates that over $50 \%$ of variability in the dependent variable is explained by the models. The RR of the cold effect at the 5 th percentile $\left(-5.51{ }^{\circ} \mathrm{C}\right)$ was 2.81 (95\% CI, 2.51-3.13) and increased to 4.89 (95\% CI, 4.13-5.80) at the minimum value $\left(-12.9^{\circ} \mathrm{C}\right)$ compared to the median $\left(7.99^{\circ} \mathrm{C}\right)$. Compared to the median, the RR of the high air pollution cumulative effect at the 95th percentile of the $\mathrm{PM}_{2.5}$ concentration was 13.18 (95\% CI, 9.02-19.28), increasing to 19.92 (95\% CI, 12.82-30.95) at the maximum value. The RRs of concentrations of $\mathrm{PM}_{10}$ were $3.34(95 \% \mathrm{CI}, 2.66-4.19)$ at the 95th percentile and $4.08(95 \% \mathrm{CI}, 3.13-5.32)$ at the maximum value compared to the median $\left(\mathrm{R}^{2}=0.343\right)$. The relative humidity displayed a weak U-shaped relationship with the number of cases. The RRs of the dry and moist effects at the 5th and 95th percentiles, respectively, were insignificant because $95 \%$ CIs included a null risk of one. The RR of the relative humidity effect peaked at $90 \%$ and reached 1.47 (95\% CI, 1.23-1.75; $\left.\mathrm{R}^{2}, 0.256\right)$.

The dry and moist effects were analyzed again using the absolute humidity calculated from relative humidity and temperature. The RR at the 5th percentile of absolute humidity $\left(3 \mathrm{~g} / \mathrm{m}^{3}\right)$ was $2.61(95 \% \mathrm{CI}, 2.36-2.88)$, whereas at the 95th percentile $\left(13 \mathrm{~g} / \mathrm{m}^{3}\right)$, the RR was 0.24 ( $95 \%$ CI, $0.20-0.28 ; R 2,0.573)$. The RR of the high wind speed cumulative effect was $3.20(95 \% \mathrm{CI}, 2.36-4.34 ; \mathrm{R} 2,0.219)$ at the 95 th percentile $(4 \mathrm{~m} / \mathrm{s})$. The RR of the effect of low sunshine hours $(0 \mathrm{~h})$ was $1.83(95 \% \mathrm{CI}, 1.36-2.44)$ and that of the low precipitation $(0 \mathrm{~mm})$ effect was 1.37 (95\% CI, 1.19-1.57). In contrast, the effect of the precipitation duration was 
positive and peaked at $9 \mathrm{~h}\left(\mathrm{RR}, 1.68 ; 95 \% \mathrm{CI}, 1.34-2.11 ; \mathrm{R}^{2}, 0.274\right)$; however, that effect was insignificant at the 95th percentile $(12 \mathrm{~h})$.

\subsection{Non-Linear Multivariable Models}

Subsequently, the above models were adjusted for $\mathrm{PM}_{2.5}$ (Figure 2). The adjusted RRs of the cold effect were 2.29 (95\% CI, 2.03-2.58) at the 5th percentile and $3.57(95 \%$ $\mathrm{CI}, 2.97-4.3)$ at the minimum value $\left(\mathrm{R}^{2}=0.703\right)$. The effect of adjusted $\mathrm{PM}_{10}$ was 1.67 (95\% CI, 1.19-2.34) at the 95th percentile and 1.82 (95\% CI, 1.22-2.69) at the maximum value $\left(R^{2}=0.548\right)$. The highest $R R$ values of relative humidity effects after including $P_{2.5}$ concentrations decreased to $1.15(95 \% \mathrm{CI}, 1.05-1.25)$ at a relative humidity of $86 \%$. When absolute humidity was analyzed, the adjusted RR of the dry effect at the 5th percentile was 2.14 (95\% CI, 1.93-2.38). The adjusted RR of the moisture effect at the 95th percentile of absolute humidity was $0.32\left(95 \% \mathrm{CI}, 0.27-0.37 ; \mathrm{R}^{2}, 0.723\right)$. The adjusted $\mathrm{RR}$ of the high wind speed cumulative effect was $2.82\left(95 \% \mathrm{CI}, 2.20-3.63 ; \mathrm{R}^{2}, 0.603\right)$. The adjusted RR of the effect of low sunshine hours $(0 \mathrm{~h})$ was $1.35\left(95 \% \mathrm{CI}, 1.07-1.71 ; \mathrm{R}^{2}, 0.616\right)$ and that of low precipitation $(0 \mathrm{~mm})$ was $1.15\left(95 \% \mathrm{CI}, 1.02-1.29 ; \mathrm{R}^{2}, 0.576\right)$. The adjusted effect of the precipitation duration peaked at $11 \mathrm{~h}\left(\mathrm{RR}, 1.48 ; 95 \% \mathrm{CI}, 1.09-2.01 ; \mathrm{R}^{2}, 0.585\right)$ but was insignificant at the 95th percentile $(12 \mathrm{~h})$.
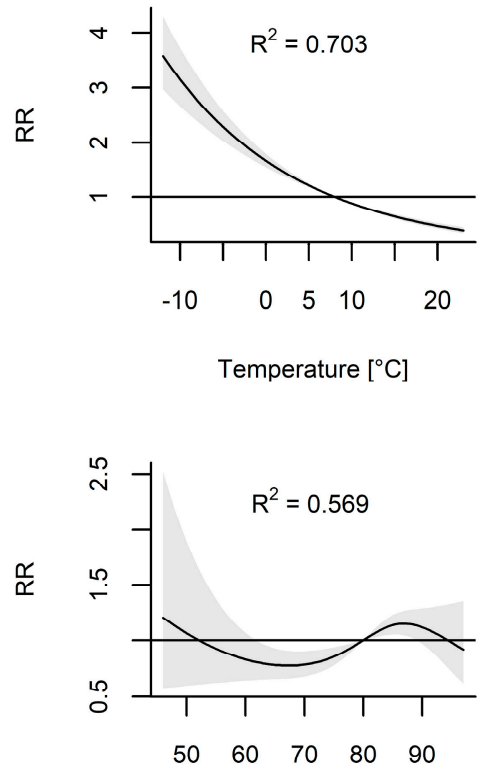

Relative humidity [\%]

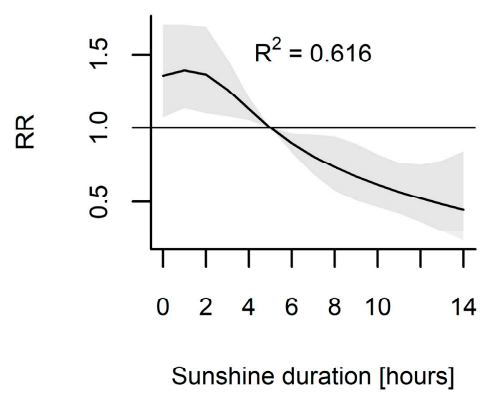

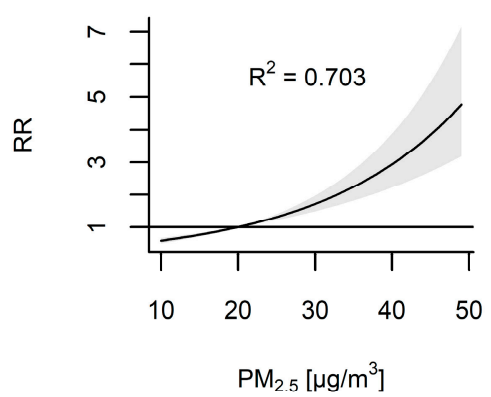

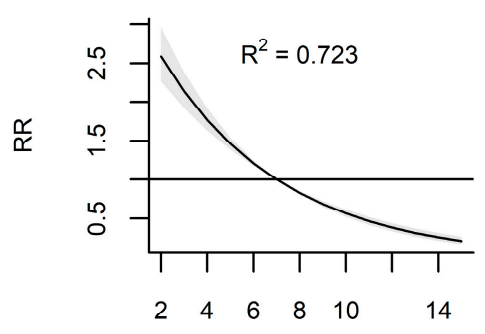

Absolute humidity $\left[\mathrm{g} / \mathrm{m}^{3}\right]$

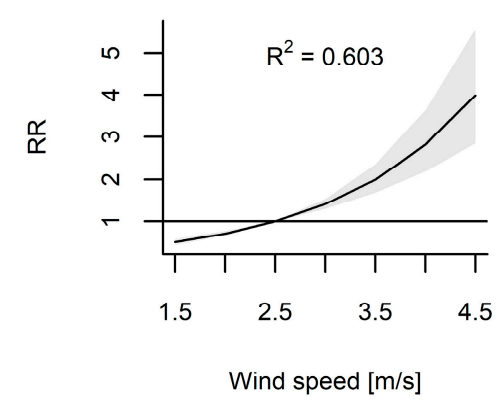

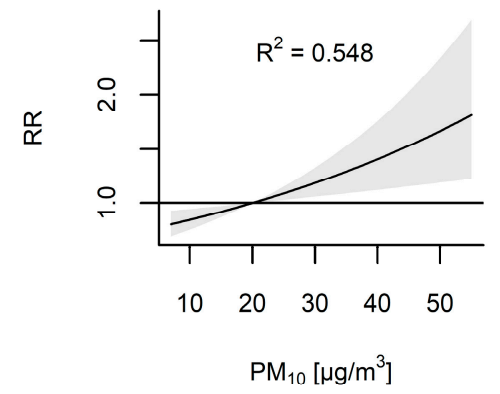

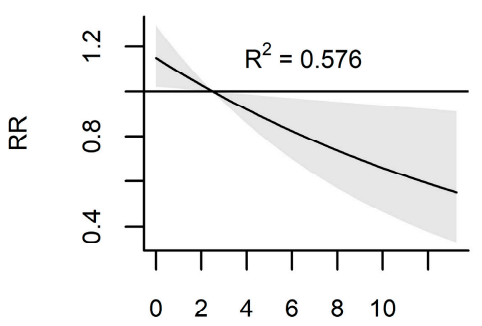

Precipitation $[\mathrm{mm}]$

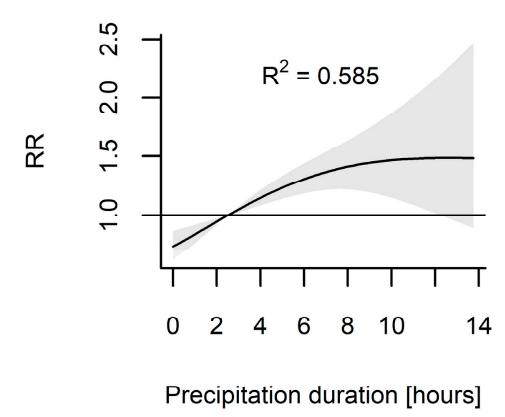

Figure 2. The association between environmental factors and the relative risk (RR) with 95\% confidence interval (CI) of influenza-like illness. The models for climatic variables were adjusted for mean concentrations of $\mathrm{PM}_{2.5}$ and the long-term trend. The models for $\mathrm{PM}_{2.5}$ and for $\mathrm{PM}_{10}$ were adjusted for the mean temperature and the long-term trend. The reference levels were defined as the median values of each of the analyzed variables to calculate RRs. 
Considering that temperature is the main driver of ILI of all meteorological factors, the air pollution effect was adjusted for mean temperatures (Figure 2). The adjusted cumulative RRs of the $\mathrm{PM}_{2.5}$ concentrations were 3.85 (95\% CI, 2.72-5.45) at the 95th percentile and 4.77 (95\% CI, 3.19-7.15) at the maximum value. The adjusted RRs of the $\mathrm{PM}_{10}$ concentrations were $1.42(1.15-1.75)$ and $1.50(1.17-1.92)$ at the 95th percentile and the maximum value, respectively $\left(\mathrm{R}^{2}=0.534\right)$. Based on the considered DLNM models, the model including $\mathrm{PM}_{2.5}$, temperature and long-term data shows the most significant association with the dynamics of ILI prevalence $\left(\mathrm{R}^{2}=0.703\right)$. Figure 3 shows the observed and predicted numbers of ILI cases in the considered time period.

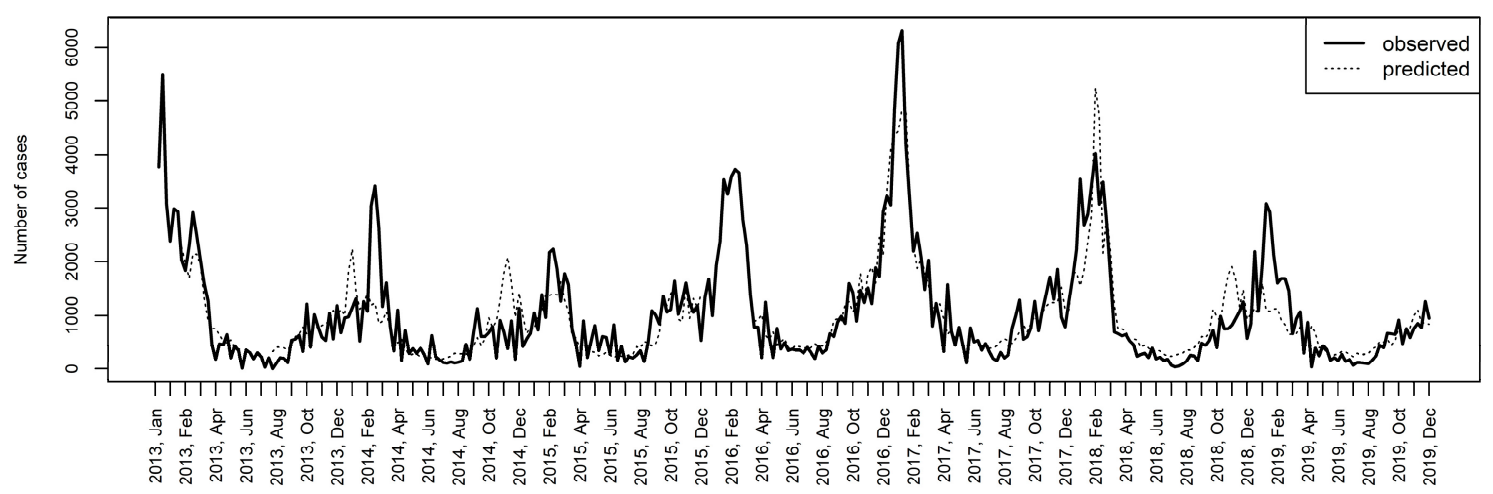

Figure 3. The observed and predicted (according to the model including temperature, $\mathrm{PM}_{2.5}$ and the long-term trend as covariates) number of influenza-like illness cases. $\mathrm{R}^{2}=0.703$.

Additionally, we considered that $\mathrm{PM}_{10}$ reflects the concentrations of both fine $\left(\mathrm{PM}_{2.5}\right)$ and coarse particles $\left(\mathrm{PM}_{10-2.5}\right)$, and therefore, the RRs of the $\mathrm{PM}_{10}$ pollution effect were analyzed in a model including the concentration of $\mathrm{PM}_{2.5}$ as a covariate. After including $\mathrm{PM}_{2.5}$ in the model, the RRs of the $\mathrm{PM}_{10}$ effect were 1.67 (95\% CI, 1.19-2.34) at the 95th percentile and 1.82 (95\% CI, 1.22-2.69) at the maximum value. Furthermore, we assessed the RRs of the cold effect adjusted for the concentrations of both $\mathrm{PM}_{2.5}$ and $\mathrm{PM}_{10}$. The adjusted RRs of the cold effect were 2.42 (95\% CI, 2.01-2.57) at the 5th percentile and 3.54 (95\% CI, 2.92-4.28) at the minimum value.

The estimated effects of the $\mathrm{PM}_{2.5}$ concentrations were plotted against lag weeks in a model including weekly mean temperatures and a long-term trend as covariates to identify the cumulative effects of $\mathrm{PM}_{2.5}$ on ILI cases (Figure $4 \mathrm{a}, \mathrm{b}$ ). The effect of $\mathrm{PM}_{2.5}$ decreased over time but remained significant for lag weeks 0 through 4 . The RRs (95\% CIs) at the 95th percentile were 1.45 (1.31-1.61), 1.37 (1.26-1.48), 1.29 (1.21-1.36), 1.21 (1.15-1.27), 1.14 (1.08-1.21), and $1.08(0.99-1.16)$ at lag weeks 0 through 5, respectively. We estimated that a $10 \mu \mathrm{g} / \mathrm{m}^{3}$ increase in the mean weekly $\mathrm{PM}_{2.5}$ concentration (an increase from 20 to $30 \mu \mathrm{g} / \mathrm{m}^{3}$ ) caused a $16 \%$ increase in the risk of ILI (RR, 1.16; 95\% CI; 1.11-1.21) in the same week (lag 0). That risk decreased over time (Figure 4c). The estimates for the five following weeks (lag 1-5) were as follows: 1.13 (95\% CI, 1.10-1.17), 1.11 (95\% CI, 1.08-1.13), 1.08 (95\% CI, 1.06-1.10), 1.05 (95\% CI, 1.03-1.08), and 1.03 (95\% CI, 1.00-1.06).

\subsection{The Effect of Wind Speed}

As indicated by the qAIC, we also assessed the effect of wind speed over lag weeks in a model including $\mathrm{PM}_{2.5}$ and a long-term trend as covariates (Figure S3, Supplementary Materials). The effect of a high wind speed decreased over time but was significant for lag weeks 0 through 2 . The RR (95\% CIs) at the 95th percentile was $1.56(1.32-1.85), 1.41$ (1.3-1.54), and $1.28(1.09-1.5)$ for lag weeks 0 through 2 , respectively. 
Lag $=0$

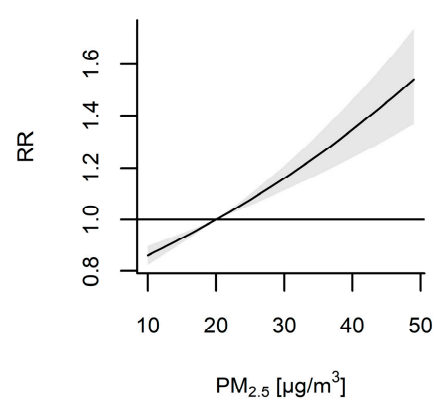

$\operatorname{Lag}=3$

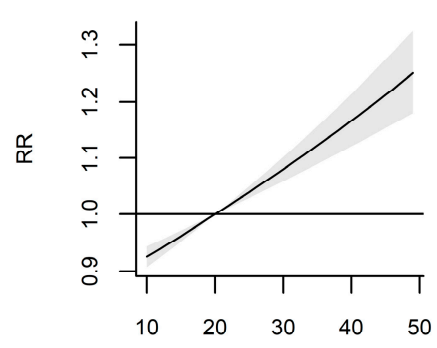

a

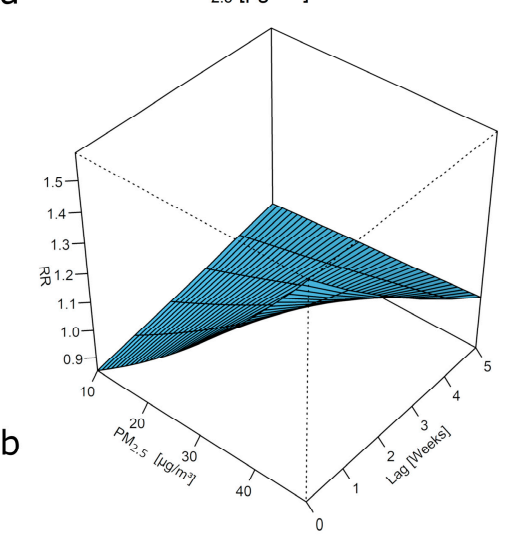

$\operatorname{Lag}=1$

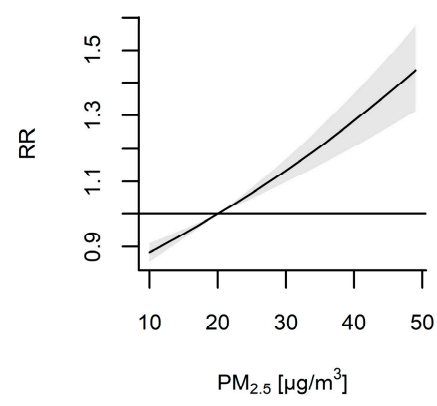

$\operatorname{Lag}=4$

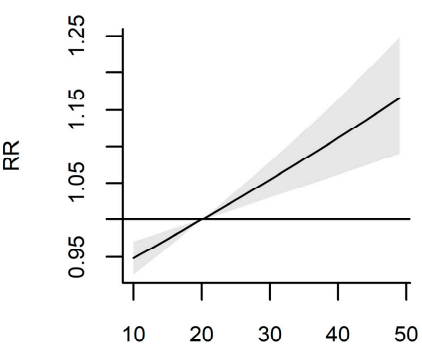

$\mathrm{PM}_{2.5}\left[\mu \mathrm{g} / \mathrm{m}^{3}\right]$
Lag $=2$
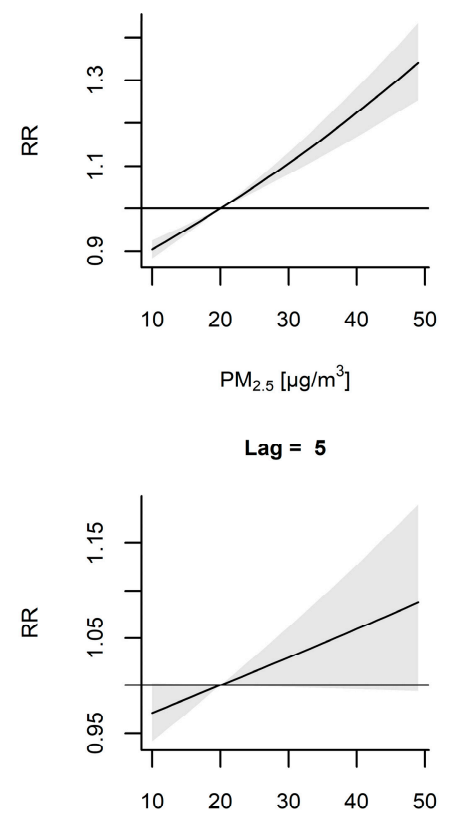

$\mathrm{PM}_{2.5}\left[\mu \mathrm{g} / \mathrm{m}^{3}\right]$

Figure 4. (a) The association between the concentration of $\mathrm{PM}_{2.5}$ and the relative risk (RR) of the incidence of influenza-like illness (ILI) is depicted as the estimated exposure-response curves for lags of 0 to 5 weeks with $95 \%$ confidence intervals (CIs). (b) The association between the concentration of $\mathrm{PM}_{2.5}$ and the RR of the incidence of ILI is depicted as the estimated exposure-lag-response surface. The model was adjusted for the mean air temperature and a long-term trend. (c) The estimated lag-response curve for $\mathrm{PM}_{2.5}=30 \mu \mathrm{g} / \mathrm{m}^{3}$ with $95 \%$ CI.

\section{Discussion}

Air pollution may increase the incidence of a wide range of diseases, including heart disease, stroke, and lung cancer [28-31]. Numerous studies have confirmed that exposure to ambient air pollutants is strongly associated with the local transmission of respiratory infections [4-6,26,32-34]. This study provides additional evidence for the association between air pollution and ILI. We have shown that the cumulative effect of an increase in the $\mathrm{PM}_{2.5}$ concentration is exponentially associated with the increase in ILI risk in Bialystok, Poland, after adjusting for air temperature and a long-term trend. The distributed lag nonlinear analysis including $\mathrm{PM}_{2.5}$, temperature and a long-term trend as covariates showed that the model was able to explain as much as $70 \%$ of the variability in the number of observed ILI cases in Bialystok, Poland in 2013-2019. The concentration of $\mathrm{PM}_{2.5}$ in Bialystok during the study, frequently exceeded the levels recommended by WHO. However, in our study, the mean $\mathrm{PM}_{2.5}$ concentrations were several times lower than those reported in previous studies linking air pollution to ILI $[4,26]$. Nevertheless, 
the effect of ambient air pollution on the ILI incidence was evident, indicating that the relationship is not limited to highly polluted regions. Moreover, the high pollution effect extended beyond the incubation periods of influenza and other respiratory tract infections, which are usually shorter than two weeks [35]. Our results show that high concentrations of $\mathrm{PM}_{2.5}$ increase the risk of ILI during the same week (lag 0 ) and for up to 4 subsequent weeks (lag weeks 1-4). Therefore, the underlying mechanisms linking air pollution and the incidence of respiratory infections are not limited to acute effects only.

The leading epidemiological concept of respiratory infections is that infections are spread by direct transmission from person to person, such as touching an infected person or touching the fomites that the infected person has contaminated. Respiratory droplets can also be deposited directly on a person in close proximity to the infected person. However, after droplets are expired, the liquid content starts to evaporate. Some droplets become so small that they are free to travel in the air and carry the pathogens contained inside over tens of meters from where they originated. Previous studies have suggested that airborne transmission should be considered possible in infections caused by influenza viruses [36-39]. The same might be hypothesized for ILI, even though pathogens other than influenza virus are frequently detected in ILI patients [40]. Multiple studies have suggested that airborne transmission participates in the spread of different respiratory pathogens responsible for ILI like, parainfluenza viruses [41], RSV [42,43], rhinoviruses [44,45], adenoviruses [46,47], human coronaviruses, including SARS-CoV-2 [48-50], and other pathogens [51].

Particulate matter may serve as a vector for the transport of pathogenic microorganisms [33,52]. The airborne transmission of pathogens further depends on their survival in aerosolized droplets, which in turn is subject to variations in temperature, humidity, and solar radiation [53]. For example, influenza virus transmission is most efficient under cold, dry conditions [54]. Both correlation and DLNM analyses revealed that temperature, absolute humidity, and wind speed were the meteorological factors that best predicted ILI activity in Bialystok, Poland. Other factors, including precipitation, sunshine duration and relative humidity, showed lower or no correlations with the incidence of ILI. Similar observations were reported in an analysis conducted in other Northern European countries [55]. We found slight inconsistencies when the Spearman analysis was done separately for the peak of the flu season only. This might be explained by the inadequacy of linear analysis in describing the complex relations between weather, air pollution, and respiratory infections. For instance, relative humidity was positively correlated with ILI in a 12-month time frame, but no correlation was found for the 3-month period from December to February. In the nonlinear analysis, an increasing trend towards low and high $\mathrm{RH}$ values with a decreased risk was observed at intermediate $\mathrm{RH}$. Thus, our results show that both high and low values of RH facilitate the spread of ILI. The results of experimental studies are consistent with these observations. In laboratory settings, influenza virus was maximally stable at low $\mathrm{RH}$, minimally stable at mid-range $\mathrm{RH}$, and moderately stable at high $\mathrm{RH}[56,57]$. However, humidity is also reported as absolute humidity, defined as the absolute amount of water in the air. We found that absolute humidity was a better predictor of ILI seasonality than relative humidity. Decreasing AH exponentially increased the risk of ILI, even if particulate matter was included in the model. Similar observations were documented in previous studies [58,59]. A positive association between ILI cases and wind speed was also noted. The effect remained significant for up to three weeks after exposure (lag weeks 0-2). Wind was shown to promote the spread of various viruses over short and large distances $[60,61]$. We hypothesize that wind facilitates the spread of ILI by transporting aerosolized pathogens in the area. The calculated lag effect of two weeks possibly reflects the maximum incubation period of respiratory pathogens causing ILI. Although the wind-borne route alone is insufficient to explain the seasonality of ILI, we show that it contributes substantially to the increase in the risk of infection.

Meteorological variables affect the concentration of particulate matter in the air; however, the interplay between these two factors is complicated. We found negative correlations between PM temperature, absolute humidity, and precipitation. The negative correlation 
between PM and temperature might be explained by emissions due to residential heating in the cold season [20]. Studies linking humidity and PM have shown conflicting results. In the analysis from the state environmental monitoring program in Poland [20], the authors described significant negative correlations between $\mathrm{PM}_{10}$ and $\mathrm{RH}$ observed in the warm season from April to September. However, a study from the USA reported a positive correlation between $\mathrm{RH}$ and $\mathrm{PM}_{2.5}$ concentrations in several regions [62]. These contradictory results may be explained by the relative abundance of each component of the PM. Sulfates and nitrates were shown to be positively related to $\mathrm{RH}$, reflecting in-cloud sulfate formation and the RH-dependent ammonium nitrate formation. The correlation between $\mathrm{RH}$ and carbons is negative, which possibly reflects sources from fires and combustion [62]. Moreover, increased RH may be accompanied by precipitation. Rainfall has a washing effect on the levels of $\mathrm{PM}_{2.5}$ in the air [63]. In the absence of precipitation, it has been suggested that PM might act as condensation nuclei for water and virus particles [33,52,64].

Notably, pathogens causing ILI differ in structure; thus, meteorological factors probably exert distinct effects on their transmission, making the data difficult to interpret. However, fluctuations in ILI activity in the community are affected not only by the transmission and survival of pathogens in the environment but also by host susceptibility. Exposure to air pollutants impacts the host response to infections. The underlying possible mechanisms related to this process are complex [65]. Ambient air pollution likely disrupts host defenses, including both innate and cell-mediated immune responses against infections. Exposure to PM containing environmentally persistent free radicals (EPFRs), which are found in most combustion-derived PM, was shown to cause pulmonary oxidative stress, which leads to local immunosuppression and the exacerbation of influenza in mice $[66,67]$. Another study reported enhanced viral attachment and entry due to exposure to diesel exhaust [68]. Particulate matter can also activate inflammatory signaling cascades, change macrophage morphology $[69,70]$ and precipitate tissue remodeling in the lung [71]. Exposure to $\mathrm{PM}_{2.5}$ alters the expression of multiple genes in lung tissue [72]. Importantly, the angiotensin-converting enzyme 2 (ACE2) receptor present on the cells was overexpressed following exposure to $\mathrm{PM}_{2.5}$. Thus, $\mathrm{PM}$ might plausibly increase the probability of SARS-CoV-2 infection, as ACE2 is the key receptor mediating virus entry [73].

The study is subject to some limitations. First, we only used two air pollution measurement sources from Bialystok City, limiting the spatial representativeness of the present analysis. People living outside Bialystok City might have been exposed to slightly different air pollution levels. A vast majority of residents of this area live in towns with similar levels of urban development; therefore, we believe that pollution levels in Bialystok City can serve as a close proxy for the County. Second, our data might potentially suffer from under-reporting of influenza cases. In our opinion, under-reporting tends to occur in consistent patterns throughout the years; hence, the seasonal variation in ILI cases still reflects the true burden of ILI in the region. Third, we did not stratify the relative risks by age group. As previously shown, the effects of air pollution depend on age [26]. Also, it has been reported that transmission of respiratory pathogens is dependent on other factors like population density [74], household size, or income [75], which were not investigated in this paper. Thus, our results cannot be generalized to the entire population, and the calculated relative risks should be interpreted with caution.

\section{Conclusions}

In conclusion, our study describes a clear association between $\mathrm{PM}_{2.5}$ pollution and the incidence of ILI in northeastern Poland, despite the relatively low concentrations of particulate matter recorded in the study period. Pollution exerted the greatest effect during the same week it was recorded, but the risk of ILI was increased in the four subsequent weeks. Because SARS-CoV-2 cases are still increasing, further studies elucidating the mechanisms linking air pollution and susceptibility to acute respiratory infections are urgently needed. 
Restrictions imposed to prevent the spread of COVID-19 reduced the concentration of $\mathrm{PM}_{2.5}$ in major Polish cities, however, it still remained above the levels recommended by WHO [76]. Globally, the effect of reduced mobility on $\mathrm{PM}_{2.5}$ was smaller than expected and probably short-term, because of the relatively small contribution of road traffic to primary $\mathrm{PM}_{2.5}$ and the large contribution from secondary precursors of PM [77]. Regardless of the limitations, the above studies clearly show that even short-term changes in anthropogenic activity can improve air quality, which in turn, might affect the susceptibility to ILI. Altogether, our study indicates that all measures implemented to decrease $\mathrm{PM}_{2.5}$ concentrations would be beneficial to reduce the transmission of COVID-19 and other respiratory infections.

Supplementary Materials: The following are available online at https://www.mdpi.com/article/ 10.3390/v13040556/s1, Table S1: Reported influenza-like illness cases in Bialystok and Bialystok County divided by year and by age group. Table S2: Annual and 24-h mean concentrations of particulate matter $\left(\mu \mathrm{g} / \mathrm{m}^{3}\right)$ in Bialystok. Table S3: Spearman's correlation coefficients between the environmental factors and the incidence of influenza-like illness. Figure S1: The number of weekly influenza-like cases (red dotted lines) plotted against meteorological and air pollution data (black lines) from Bialystok, Poland, from January 2013-December 2019. Figure S2: The association between environmental factors and the relative risk (RR) with $95 \%$ confidence interval of influenza-like illness. The analysis was performed for each environmental factor separately. The reference levels were defined as the median values of each of the analyzed variables to calculate RRs. Figure S3: The association between wind speed and the relative risk (RR) of the incidence of influenza-like illness is shown as the estimated exposure-lag-response curves for lags of 0 to 2 weeks with $95 \%$ confidence intervals. The model was adjusted for the $\mathrm{PM}_{2.5}$ concentration and a long-term trend.

Author Contributions: Conceptualization, K.T.; Data curation, K.T.; Funding acquisition, K.T.; Methodology, K.T. and M.W.-P.; Supervision, M.G. and A.S.; Visualization, K.T. and M.W.-P.; Writingoriginal draft, K.T. and M.W.-P.; Writing—review \& editing, K.T., M.W.-P., Magdalena Grabowska and A.S. All authors have read and agreed to the published version of the manuscript.

Funding: This research was funded by the Medical University of Bialystok, grant number SUB/1/DN /21/002/1148. The APC was funded by the Medical University of Bialystok.

Institutional Review Board Statement: The study was conducted according to the guidelines of the Declaration of Helsinki, and approved by the Ethics Committee of the Medical University of Bialystok (protocol code APK.002.420.2020 approved on 17 December 2020).

Informed Consent Statement: Not applicable.

Data Availability Statement: The data presented in this study are available on request from the corresponding author.

Acknowledgments: We would like to thank Pawel Kowalski from the Chief Inspectorate of Environmental Protection for his help in data interpretation. We would also like to thank Waldemar Kulesza and all the staff at the Department of Epidemiology of the Municipal Sanitary and Epidemiological Station in Bialystok for kindly sharing the epidemiological data.

Conflicts of Interest: The authors declare no conflict of interest. The funders had no role in the design of the study; in the collection, analyses, or interpretation of data; in the writing of the manuscript, or in the decision to publish the results.

\section{References}

1. WHO. Air Quality Guidelines: Global Update 2005: Particulate Matter, Ozone, Nitrogen Dioxide, and Sulfur Dioxide; World Health Organization: Geneva, Switzerland, 2006; ISBN 978-92-890-2192-0.

2. Kim, K.-H.; Kabir, E.; Kabir, S. A review on the human health impact of airborne particulate matter. Environ. Int. 2015, 74, 136-143. [CrossRef] [PubMed]

3. Sun, Q.; Hong, X.; Wold, L.E. Cardiovascular Effects of Ambient Particulate Air Pollution Exposure. Circulation 2010, 121, 2755-2765. [CrossRef]

4. Huang, L.; Zhou, L.; Chen, J.; Chen, K.; Liu, Y.; Chen, X.; Tang, F. Acute effects of air pollution on influenza-like illness in Nanjing, China: A population-based study. Chemosphere 2016, 147, 180-187. [CrossRef] [PubMed] 
5. Silva, D.R.; Viana, V.P.; Müller, A.M.; Livi, F.P.; Dalcin, P.D.T.R. Respiratory viral infections and effects of meteorological parameters and air pollution in adults with respiratory symptoms admitted to the emergency room. Influ. Other Respir. Viruses 2014, 8, 42-52. [CrossRef] [PubMed]

6. Su, W.; Wu, X.; Geng, X.; Zhao, X.; Liu, Q.; Liu, T. The short-term effects of air pollutants on influenza-like illness in Jinan, China. BMC Public Heal. 2019, 19, 1-12. [CrossRef] [PubMed]

7. Jiang, Y.; Wu, X.-J.; Guan, Y.-J. Effect of ambient air pollutants and meteorological variables on COVID-19 incidence. Infect. Control. Hosp. Epidemiol. 2020, 41, 1011-1015. [CrossRef]

8. Fukuda, K.; WHO (Eds.) Pandemic Influenza Preparedness and Response: A WHO Guidance Document; World Health Organization: Geneva, Switzerland, 2009; ISBN 978-92-4-154768-0.

9. Feng, L.; Feng, S.; Chen, T.; Yang, J.; Lau, Y.C.; Peng, Z.; Li, L.; Wang, X.; Wong, J.Y.T.; Qin, Y.; et al. Burden of influenza-associated outpatient influenza-like illness consultations in China, 2006-2015: A population-based study. Influ. Other Respir. Viruses 2019, 14, 162-172. [CrossRef]

10. Tsai, Y.; Zhou, F.; Kim, I.K. The burden of influenza-like illness in the US workforce. Occup. Med. 2014, 64, 341-347. [CrossRef]

11. Air Quality Statistics-European Environment Agency. Available online: https://www.eea.europa.eu/data-and-maps/ dashboards / air-quality-statistics (accessed on 19 August 2020).

12. Juda-Rezler, K.; Reizer, M.; Maciejewska, K.; Błaszczak, B.; Klejnowski, K. Characterization of atmospheric PM2.5 sources at a Central European urban background site. Sci. Total. Environ. 2020, 713, 136729. [CrossRef]

13. Slama, A.; Śliwczyński, A.; Woźnica, J.; Zdrolik, M.; Wiśnicki, B.; Kubajek, J.; Turżańska-Wieczorek, O.; Gozdowski, D.; Wierzba, W.; Franek, E. Impact of air pollution on hospital admissions with a focus on respiratory diseases: A time-series multi-city analysis. Environ. Sci. Pollut. Res. 2019, 26, 16998-17009. [CrossRef]

14. Liu, X.-X.; Li, Y.; Qin, G.; Zhu, Y.; Li, X.; Zhang, J.; Zhao, K.; Hu, M.; Wang, X.-L.; Zheng, X. Effects of air pollutants on occurrences of influenza-like illness and laboratory-confirmed influenza in Hefei, China. Int. J. Biometeorol. 2018, 63, 51-60. [CrossRef] [PubMed]

15. Xu, Z.; Hu, W.; Williams, G.; Clements, A.C.; Kan, H.; Tong, S. Air pollution, temperature and pediatric influenza in Brisbane, Australia. Environ. Int. 2013, 59, 384-388. [CrossRef]

16. Boëlle, P.-Y.; Souty, C.; Launay, T.; Guerrisi, C.; Turbelin, C.; Behillil, S.; Enouf, V.; Poletto, C.; Lina, B.; Van Der Werf, S.; et al. Excess cases of influenza-like illnesses synchronous with coronavirus disease (COVID-19) epidemic, France, March 2020. Eurosurveillance 2020, 25, 2000326. [CrossRef]

17. Kong, W.-H.; Li, Y.; Peng, M.-W.; Kong, D.-G.; Yang, X.-B.; Wang, L.; Liu, M.-Q. SARS-CoV-2 detection in patients with influenza-like illness. Nat. Microbiol. 2020, 5, 675-678. [CrossRef]

18. Yu, X.; Wei, D.; Chen, Y.; Zhang, D.; Zhang, X. Retrospective detection of SARS-CoV-2 in hospitalized patients with influenza-like illness. Emerg. Microbes Infect. 2020, 9, 1470-1473. [CrossRef]

19. Conticini, E.; Frediani, B.; Caro, D. Can atmospheric pollution be considered a co-factor in extremely high level of SARS-CoV2 lethality in Northern Italy? Environ. Pollut. 2020, 261, 114465. [CrossRef]

20. Poland State Inspection for Environmental Protection; Chief Inspectorate of Environmental Protection. Fine Particles in the Atmosphere: A Compendium of Knowledge about Particulate Matter Air Pollution in Poland; Degórska, A., Juda-Rezler, K., Toczko, B., Eds.; Chief Inspectorate of Environmental Protection: Warsaw, Poland, 2016; ISBN 978-83-61227-73-1.

21. Statistics Poland-Local Data Bank. Available online: https://bdl.stat.gov.pl (accessed on 4 August 2020).

22. Merkel, A. Climate-Data.Org. Available online: https://en.climate-data.org/europe/poland/podlaskie-voivodeship/bia $\%$ C5\%8 2ystok-1031/ (accessed on 9 January 2020).

23. Gasparrini, A.; Armstrong, B.; Kenward, M.G. Distributed lag non-linear models. Stat. Med. 2010, 29, 2224-2234. [CrossRef]

24. Burnham, K.P.; Anderson, D.R. Model Selection and Inference: A Practical Information-Theoretic Approach; Springer: New York, NY, USA, 1998; ISBN 978-1-4757-2917-7.

25. Liang, Y.; Fang, L.; Pan, H.; Zhang, K.; Kan, H.; Brook, J.R.; Sun, Q. PM2.5 in Beijing-temporal pattern and its association with influenza. Environ. Health 2014, 13, 1-8. [CrossRef]

26. Feng, C.; Li, J.; Sun, W.; Zhang, Y.; Wang, Q. Impact of ambient fine particulate matter (PM2.5) exposure on the risk of influenza-like-illness: A time-series analysis in Beijing, China. Environ. Health 2016, 15, 1-12. [CrossRef] [PubMed]

27. Vandini, S.; Corvaglia, L.; Alessandroni, R.; Aquilano, G.; Marsico, C.; Spinelli, M.; Lanari, M.; Faldella, G. Respiratory syncytial virus infection in infants and correlation with meteorological factors and air pollutants. Ital. J. Pediatr. 2013, 39, 1. [CrossRef] [PubMed]

28. Brunekreef, B.; Holgate, S.T. Air pollution and health. Lancet 2002, 360, 1233-1242. [CrossRef]

29. Laden, F.; Neas, L.M.; Dockery, D.W.; Schwartz, J. Association of fine particulate matter from different sources with daily mortality in six U.S. cities. Environ. Health Perspect. 2000, 108, 941-947. [CrossRef]

30. Polichetti, G.; Cocco, S.; Spinali, A.; Trimarco, V.; Nunziata, A. Effects of particulate matter (PM10, PM2.5 and PM1) on the cardiovascular system. Toxicology 2009, 261, 1-8. [CrossRef] [PubMed]

31. Raaschou-Nielsen, O.; Andersen, Z.J.; Beelen, R.; Samoli, E.; Stafoggia, M.; Weinmayr, G.; Hoffmann, B.; Fischer, P.; Nieuwenhuijsen, M.J.; Brunekreef, B.; et al. Air pollution and lung cancer incidence in 17 European cohorts: Prospective analyses from the European Study of Cohorts for Air Pollution Effects (ESCAPE). Lancet Oncol. 2013, 14, 813-822. [CrossRef] 
32. Domingo, J.L.; Rovira, J. Effects of air pollutants on the transmission and severity of respiratory viral infections. Environ. Res. 2020, 187, 109650. [CrossRef] [PubMed]

33. Chen, P.-S.; Tsai, F.T.; Lin, C.K.; Yang, C.-Y.; Chan, C.-C.; Young, C.-Y.; Lee, C.-H. Ambient Influenza and Avian Influenza Virus during Dust Storm Days and Background Days. Environ. Health Perspect. 2010, 118, 1211-1216. [CrossRef]

34. Lindner-Cendrowska, K.; Bröde, P. Impact of biometeorological conditions and air pollution on influenza-like illnesses incidence in Warsaw. Int. J. Biometeorol. 2021, 1-16. [CrossRef]

35. Stellrecht, K.A. Chapter 11-Molecular Testing for Respiratory Viruses. In Diagnostic Molecular Pathology; Coleman, W.B., Tsongalis, G.J., Eds.; Academic Press: Cambridge, MA, USA, 2017; pp. 123-137. ISBN 978-0-12-800886-7.

36. Cowling, B.J.; Ip, D.K.M.; Fang, V.J.; Suntarattiwong, P.; Olsen, S.J.; Levy, J.; Uyeki, T.M.; Leung, G.M.; Peiris, J.S.M.; Chotpitayasunondh, T.; et al. Aerosol transmission is an important mode of influenza A virus spread. Nat. Commun. 2013, 4, 1-6. [CrossRef]

37. Tellier, R.; Li, Y.; Cowling, B.J.; Tang, J.W. Recognition of aerosol transmission of infectious agents: A commentary. BMC Infect. Dis. 2019, 19, 1-9. [CrossRef]

38. Tellier, R. Aerosol transmission of influenza A virus: A review of new studies. J. R. Soc. Interface 2009, 6, S783-S790. [CrossRef]

39. Hammond, G.W.; Raddatz, R.L.; Gelskey, D.E. Impact of Atmospheric Dispersion and Transport of Viral Aerosols on the Epidemiology of Influenza. Clin. Infect. Dis. 1989, 11, 494-497. [CrossRef] [PubMed]

40. Thomas, R.E. Is influenza-like illness a useful concept and an appropriate test of influenza vaccine effectiveness? Vaccine 2014, 32, 2143-2149. [CrossRef] [PubMed]

41. Burke, C.W.; Bridges, O.; Brown, S.; Rahija, R.; Russell, C.J. Mode of Parainfluenza Virus Transmission Determines the Dynamics of Primary Infection and Protection from Reinfection. PLoS Pathog. 2013, 9, e1003786. [CrossRef] [PubMed]

42. Kulkarni, H.; Smith, C.; Hirst, R.; Baker, N.; Easton, A.; O'Callaghan, C. Airborne Transmission of Respiratory Syncytial Virus (RSV) Infection. Eur. Respir. J. 2011, 38, 1722.

43. Aintablian, N.; Walpita, P.; Sawyer, M.H. Detection of Bordetella pertussis and Respiratory Syncytial Virus in Air Samples from Hospital Rooms. Infect. Control. Hosp. Epidemiol. 1998, 19, 918-923. [CrossRef]

44. Dick, E.C.; Jennings, L.C.; Mink, K.A.; Wartgow, C.D.; Inborn, S.L. Aerosol Transmission of Rhinovirus Colds. J. Infect. Dis. 1987, 156, 442-448. [CrossRef] [PubMed]

45. Myatt, T.A.; Johnston, S.L.; Zuo, Z.; Wand, M.; Kebadze, T.; Rudnick, S.; Milton, D.K. Detection of Airborne Rhinovirus and Its Relation to Outdoor Air Supply in Office Environments. Am. J. Respir. Crit. Care Med. 2004, 169, 1187-1190. [CrossRef]

46. Couch, R.B.; Cate, T.R.; Fleet, W.F.; Gerone, P.J.; Knight, V. Aerosol-induced adenoviral illness resembling the naturally occurring illness in military recruits. Am. Rev. Respir. Dis. 1966, 93, 529-535.

47. Echavarria, M.; Kolavic, S.A.; Cersovsky, S.; Mitchell, F.; Sanchez, J.L.; Polyak, C.; Innis, B.L.; Binn, L.N. Detection of Adenoviruses $(\mathrm{AdV})$ in Culture-Negative Environmental Samples by PCR during an AdV-Associated Respiratory Disease Outbreak. J. Clin. Microbiol. 2000, 38, 2982-2984. [CrossRef]

48. Da Silva, P.G.; Nascimento, M.S.J.; Soares, R.R.; Sousa, S.I.; Mesquita, J.R. Airborne spread of infectious SARS-CoV-2: Moving forward using lessons from SARS-CoV and MERS-CoV. Sci. Total. Environ. 2021, 764, 142802. [CrossRef]

49. Yu, I.T.; Li, Y.; Wong, T.W.; Tam, W.; Chan, A.T.; Lee, J.H.; Leung, D.Y.; Ho, T. Evidence of Airborne Transmission of the Severe Acute Respiratory Syndrome Virus. New Engl. J. Med. 2004, 350, 1731-1739. [CrossRef] [PubMed]

50. Morawska, L.; Cao, J. Airborne transmission of SARS-CoV-2: The world should face the reality. Environ. Int. 2020, 139, 105730. [CrossRef] [PubMed]

51. Tang, J.; Li, Y.; Eames, I.; Chan, P.; Ridgway, G. Factors involved in the aerosol transmission of infection and control of ventilation in healthcare premises. J. Hosp. Infect. 2006, 64, 100-114. [CrossRef] [PubMed]

52. Griffin, D.W.; Garrison, V.H.; Herman, J.R.; Shinn, E.A. African desert dust in the Caribbean atmosphere: Microbiology and public health. Aerobiology 2001, 17, 203-213. [CrossRef]

53. Sooryanarain, H.; Elankumaran, S. Environmental Role in Influenza Virus Outbreaks. Annu. Rev. Anim. Biosci. 2015, 3, 347-373. [CrossRef]

54. Lowen, A.C.; Steel, J. Roles of Humidity and Temperature in Shaping Influenza Seasonality. J. Virol. 2014, 88, 7692-7695. [CrossRef]

55. Ianevski, A.; Zusinaite, E.; Shtaida, N.; Kallio-Kokko, H.; Valkonen, M.; Kantele, A.; Telling, K.; Lutsar, I.; Letjuka, P.; Metelitsa, N.; et al. Low Temperature and Low UV Indexes Correlated with Peaks of Influenza Virus Activity in Northern Europe during 2010-2018. Viruses 2019, 11, 207. [CrossRef]

56. Lowen, A.C.; Mubareka, S.; Steel, J.; Palese, P. Influenza Virus Transmission Is Dependent on Relative Humidity and Temperature. PLOS Pathog. 2007, 3, e151. [CrossRef]

57. Schaffer, F.L.; Soergel, M.E.; Straube, D.C. Survival of airborne influenza virus: Effects of propagating host, relative humidity, and composition of spray fluids. Arch. Virol. 1976, 51, 263-273. [CrossRef]

58. Tamerius, J.D.; Shaman, J.; Alonso, W.J.; Bloom-Feshbach, K.; Uejio, C.K.; Comrie, A.; Viboud, C. Environmental Predictors of Seasonal Influenza Epidemics across Temperate and Tropical Climates. PLOS Pathog. 2013, 9, e1003194. [CrossRef]

59. Shoji, M.; Katayama, K.; Sano, K. Absolute Humidity as a Deterministic Factor Affecting Seasonal Influenza Epidemics in Japan. Tohoku J. Exp. Med. 2011, 224, 251-256. [CrossRef] 
60. Sundell, N.; Andersson, L.-M.; Brittain-Long, R.; Lindh, M.; Westin, J. A four year seasonal survey of the relationship between outdoor climate and epidemiology of viral respiratory tract infections in a temperate climate. J. Clin. Virol. 2016, 84, 59-63. [CrossRef] [PubMed]

61. Ypma, R.J.; Jonges, M.; Bataille, A.; Stegeman, A.; Koch, G.; Van Boven, M.; Koopmans, M.; Van Ballegooijen, W.M.; Wallinga, J. Genetic Data Provide Evidence for Wind-Mediated Transmission of Highly Pathogenic Avian Influenza. J. Infect. Dis. 2012, 207, 730-735. [CrossRef]

62. Tai, A.P.K.; Mickley, L.J.; Jacob, D.J. Correlations between fine particulate matter (PM2.5) and meteorological variables in the United States: Implications for the sensitivity of PM2.5 to climate change. Atmos. Environ. 2010, 44, 3976-3984. [CrossRef]

63. Ouyang, W.; Guo, B.; Cai, G.; Li, Q.; Han, S.; Liu, B.; Liu, X. The washing effect of precipitation on particulate matter and the pollution dynamics of rainwater in downtown Beijing. Sci. Total. Environ. 2015, 505, 306-314. [CrossRef] [PubMed]

64. Liu, P.; Song, M.; Zhao, T.; Gunthe, S.S.; Ham, S.; He, Y.; Qin, Y.M.; Gong, Z.; Amorim, J.C.; Bertram, A.K.; et al. Resolving the mechanisms of hygroscopic growth and cloud condensation nuclei activity for organic particulate matter. Nat. Commun. 2018, 9 , 1-10. [CrossRef]

65. Ciencewicki, J.; Jaspers, I. Air Pollution and Respiratory Viral Infection. Inhal. Toxicol. 2007, 19, 1135-1146. [CrossRef] [PubMed]

66. Saravia, J.; You, D.; Thevenot, P.; Lee, G.I.; Shrestha, B.; Lomnicki, S.; Cormier, S.A. Early-life exposure to combustion-derived particulate matter causes pulmonary immunosuppression. Mucosal Immunol. 2014, 7, 694-704. [CrossRef] [PubMed]

67. I Lee, G.; Saravia, J.; You, D.; Shrestha, B.; Jaligama, S.; Hebert, V.Y.; Dugas, T.R.; A Cormier, S. Exposure to combustion generated environmentally persistent free radicals enhances severity of influenza virus infection. Part. Fibre Toxicol. 2014, 11, 1-10. [CrossRef]

68. Jaspers, I.; Ciencewicki, J.M.; Zhang, W.; Brighton, L.E.; Carson, J.L.; Beck, M.A.; Madden, M.C. Diesel Exhaust Enhances Influenza Virus Infections in Respiratory Epithelial Cells. Toxicol. Sci. 2005, 85, 990-1002. [CrossRef]

69. Li, N.; Harkema, J.R.; Lewandowski, R.P.; Wang, M.; Bramble, L.A.; Gookin, G.R.; Ning, Z.; Kleinman, M.T.; Sioutas, C.; Nel, A.E. Ambient ultrafine particles provide a strong adjuvant effect in the secondary immune response: Implication for traffic-related asthma flares. Am. J. Physiol. Cell. Mol. Physiol. 2010, 299, L374-L383. [CrossRef]

70. Yang, J.; Chen, Y.; Yu, Z.; Ding, H.; Ma, Z. The influence of PM2.5 on lung injury and cytokines in mice. Exp. Ther. Med. 2019, 18, 2503-2511. [CrossRef]

71. E Pinkerton, K.; Green, F.H.; Saiki, C.; Vallyathan, V.; Plopper, C.G.; Gopal, V.; Hung, D.; Bahne, E.B.; Lin, S.S.; Ménache, M.G.; et al. Distribution of particulate matter and tissue remodeling in the human lung. Environ. Health Perspect. 2000, 108, 1063-1069. [CrossRef]

72. Sancini, G.; Farina, F.; Battaglia, C.; Cifola, I.; Mangano, E.; Mantecca, P.; Camatini, M.; Palestini, P. Health Risk Assessment for Air Pollutants: Alterations in Lung and Cardiac Gene Expression in Mice Exposed to Milano Winter Fine Particulate Matter (PM2.5). PLoS ONE 2014, 9, e109685. [CrossRef] [PubMed]

73. Comunian, S.; Dongo, D.; Milani, C.; Palestini, P. Air Pollution and COVID-19: The Role of Particulate Matter in the Spread and Increase of COVID-19's Morbidity and Mortality. Int. J. Environ. Res. Public Heal. 2020, 17, 4487. [CrossRef] [PubMed]

74. Hu, H.; Nigmatulina, K.; Eckhoff, P. The scaling of contact rates with population density for the infectious disease models. Math. Biosci. 2013, 244, 125-134. [CrossRef] [PubMed]

75. Chen, Y.; Williams, E.; Kirk, M. Risk Factors for Acute Respiratory Infection in the Australian Community. PLoS ONE 2014, 9 , e101440. [CrossRef] [PubMed]

76. Filonchyk, M.; Hurynovich, V.; Yan, H. Impact of Covid-19 lockdown on air quality in the Poland, Eastern Europe. Environ. Res. 2020, 110454. [CrossRef]

77. Shi, Z.; Song, C.; Liu, B.; Lu, G.; Xu, J.; Van Vu, T.; Elliott, R.J.R.; Li, W.; Bloss, W.J.; Harrison, R.M. Abrupt but smaller than expected changes in surface air quality attributable to COVID-19 lockdowns. Sci. Adv. 2021, 7, eabd6696. [CrossRef] 